\title{
HUBUNGAN TINGKAT PENGETAHUAN DAN SIKAP MASYARAKAT TERHADAP KEPATUHAN PENERAPAN 3M DALAM RANGKA PENCEGAHAN COVID-19 DI RT 11 RW 12 JATINEGARA JAKARTA TIMUR
}

\author{
Festi Ladyani Mustofa ${ }^{1}$, Ismalia Husna ${ }^{2}$, Marisa Anggraini ${ }^{3}$, Ronal Angga \\ Putra $^{4}$
}

\author{
${ }^{1}$ Departemen Gizi Medik Fakultas Kedokteran Universitas Malahayati \\ ${ }^{2}$ Departemen Parasitologi Fakultas Kedokteran Universitas Malahayati \\ ${ }^{3}$ Departemen Ilmu Kedokteran Komunitas Fakultas Kedokteran Universitas \\ Malahayati \\ ${ }^{4}$ Program Studi Kedokteran Fakultas Kedokteran Universitas Malahayati \\ [email korespondensi: ronalangga05@gmail.com]
}

\begin{abstract}
Relationship between Knowledge Level and Community Attitude Towards Compliance with 3M Implementation in the Context of COVID-19 Prevention at RT 11 RW 12 Jatinegara East Jakarta. Coronavirus disease 2019 (COVID-19) is a disease caused by infection with the new corona virus strain which was first reported at the end of 2019. Knowledge is the result of a person's sensing of a certain object. Attitude is a person's closed response to a stimulus or object. The goal is to find out the relationship between the level of knowledge and public attitudes towards compliance with $3 \mathrm{M}$ implementation in the context of preventing COVID-19 at RT.11 / RW.12 Jatinegara Village, East Jakarta. This type of research is analytic with a cross sectional approach using a questionnaire. The sample of this research is 128 residents of RT.11 / RW.12 Jatinegara, East Jakarta. Data analysis used chi square statistical test. The results obtained were 14 people with poor knowledge $(10.9 \%)$, and 114 people with good knowledge $(89.1 \% \%)$. Residents with negative attitudes 20 people $(15.6 \%)$ and positive attitudes 108 people $(84.4 \%)$. There are 45 people $(35.2 \%)$ who have poor compliance with $3 \mathrm{M}$ implementation, and 83 people $(64.8 \%)$ are good at it. There is a relationship between knowledge $(p=0.034)$ and attitude $(p=0.00)$ with 3M implementation compliance. In conclusion, there is a significant relationship between knowledge ( $p$ $=0.034)$ and attitude $(p=0.000)$ with $3 \mathrm{M}$ application compliance.
\end{abstract}

Keywords: Knowledge, Attitude, Compliance, 3M Application

\begin{abstract}
Abstrak: Hubungan Tingkat Pengetahuan dan Sikap Masyarakat Terhadap Kepatuhan Penerapan 3M Dalam Rangka Pencegahan COVID-19 di RT 11 RW 12 Jatinegara Jakarta Timur. Coronavirus disease 2019 (COVID-19) adalah suatu penyakit yang disebabkan oleh infeksi virus corona strain baru yang dilaporkan pertama kali akhir tahun 2019. Pengetahuan adalah hasil penginderaan seseorang terhadap suatu objek tertentu. Sikap adalah respon tertutup seseorang terhadap stimulus atau objek. Tujuannya Untuk Mengetahui hubungan antara tingkat pengetahuan dan sikap masyarakat terhadap kepatuhan penerapan 3M dalam rangka pencegahan COVID-19 di RT.11/RW.12 Kelurahan Jatinegara Jakarta Timur. Jenis penelitian ini adalah Analitik dengan pendekatan cross sectional menggunakan kuesioner. Sampel penelitian ini adalah warga RT.11/RW.12 Jatinegara Jakarta Timur sebanyak 128 orang. Analisis data menggunakan uji statistic chi square. Hasil yang didapatkan adalah warga dengan pengetahuan kurang baik 14 orang $(10,9 \%)$, dan pengetahuan baik 114 orang $(89,1 \% \%)$. Warga dengan sikap negatif 20 orang $(15,6 \%)$ dan sikap positif 108 orang $(84,4 \%)$. Kepatuhan penerapan 3M kurang baik pada warga berjumlah 45 orang $(35,2 \%)$, dan baik berjumlah 83 orang $(64,8 \%)$. Ada hubungan antara pengetahuan $(p=0,034)$ dan sikap $(p=0,00)$ dengan kepatuhan penerapan 3M. Kesimpulannya Terdapat hubungan yang signifikan antara pengetahuan $(p=0,034)$ dan sikap $(p=0,000)$ dengan kepatuhan penerapan 3M.
\end{abstract}

Kata Kunci: Pengetahuan, Sikap, Kepatuhan, Penerapan 3M 


\section{PENDAHULUAN}

Coronavirus Disease 2019 (COVID-19) adalah suatu penyakit yang disebabkan oleh virus Sars-CoV-2. Setidaknya terdapat dua penyakit yang dapat disebabkan oleh virus tersebut diantaranya Middle East Respiratory Syndrome (MERS) dan Severe Acute Respiratory Syndrome (SARS). Coronavirus merupakan salah satu jenis virus yang masuk kedalam golongan zoonosis (ditularkan antara hewan dan manusia) (Isbaniyah et al., 2020).

COVID-19 pertama kali

dilaporkan pada tanggal 31 Desember 2019 di Kota Wuhan, Provinsi Hubei, China (WHO, 2020). Pada tanggal 2 Maret 2020 muncul laporan kasus pertama kali di Indonesia ketika dua orang warga negara Indonesia terkonfirmasi tertular oleh warga negara Jepang yang sedang berkunjung ke Indonesia (Yulisman, 2020). Angka kasus laporan COVID-19 di Indonesia terus meningkat drastis sejalannya waktu, bahkan hingga sampai saat ini pada tanggal 16 November 2020 sudah ada 119.633 jumlah kasus terkonfirmasi (Pemprov DKI Jakarta, 2020).

Dari 34 Provinsi di Indonesia, Jakarta menduduki posisi pertama dengan jumlah kasus COVID-19 terbanyak. Pada tanggal 16 November 2020 terdapat 119.633 jumlah kasus terkonfirmasi. Diantaranya 2.537 $(2,12 \%)$ dirawat, $110.221 \quad$ (92.13) sembuh, 2.455 (2,06\%) meninggal, dan $4.420(3,69 \%)$ isolasi mandiri. $\mathrm{Di}$ Kelurahan Jatinegara sendiri terdapat 704 kasus positif diantaranya $9(1,28 \%)$ dirawat, 651 (92,47\%) sembuh, 11 $(1,56 \%)$ meninggal, dan $33(4,69 \%)$ isolasi mandiri (Pemprov DKI Jakarta, 2020).

Terdapat tiga langkah dasar pencegahan COVID-19 yang biasa disebut 3M memakai masker, menjaga jarak, dan mencuci tangan dengan sabun di air mengalir. Selain itu menjaga imunitas tubuh dan gaya hidup yang sehat juga harus diterapkan agar angka kasus COVID-19 dapat ditekan. Disamping itu pemerintah juga harus tetap melakukan langkah 3T Testing, Tracing, dan Treatment.(Isbaniyah et al., 2020).
Di Indonesia, saat ini pemerintah sudah mulai menerapkan konsep new normal yaitu masyarakat harus tetap menjaga produktivitas di era Pandemi COVID-19 (Pemprov DKI Jakarta, 2020).Disamping itu juga tetap harus melaksanakan konsep 3M (memakai masker, menjaga jarak, mencuci tangan dengan sabun di air mengalir) juga harus diterapkan masyarakat saat berpergian dan beraktifitas. Di Jakarta sendiri penggunaan masker saat bepergian keluar rumah sudah diatur oleh Pergub Nomor 79 Tahun 2020(Pemprov DKI Jakarta, 2020).Tentang penerapan disiplin dan hukum protokol kesehatan sebagai upaya pencegahan COVID-19. Dalam pasal 4 ayat (1) huruf a dikenakan sanksi kerja sosial membersihkan sarana fasilitas umum dengan menggunakan rompi selama 60 (enam puluh) menit atau denda administratif paling banyak Rp. 250.000 (dua ratus lima puluh ribu rupiah). Selama peraturan itu telah ditetapkan masih ada warga di lingkungan tempat tinggal peneliti yaitu warga RT.11/RW.12 Jatinegara Jakarta Timur yang enggan menerapkan 3M.

Hal ini dapat diperkuat berdasarkan survei awal yang dilakukan oleh peneliti dimana masih terdapat warga yang tidak menggunakan masker, dan beberapa orang di tempat umum yang tidak menjaga jarak.

Menurut hasil survei awal yang dilakukan oleh peneliti di RT.11/RW.12 Jatinegara Jakarta Timur dimana diantara 20 orang yang diobservasi masih terdapat 9 orang yang tidak menggunakan masker ketika berada di luar rumah, dan juga masih terdapat 4 titik lokasi yang masih tidak menerapkan jaga jarak di lingkungan RT.11/ RW.12 Jatinegara Jakarta Timur baik di warung, Bengkel, ataupun tempat umum lainnya. Padahal di RT.11/RW.12 Kelurahan Jatinegara Jakarta Timur sendiri sudah terdapat 38 orang yang terkonfirmasi COVID-19. Berdasarkan hasil observasi tersebut, maka peneliti tertarik untuk melakukan penelitian tentang tingkat pengetahuan dan sikap masyarakat terhadap kepatuhan penerapan 3M dalam rangka 
pencegahan COVID-19 di RT.11/RW.12 Kelurahan Jatinegara Jakarta Timur.

\section{METODE}

Jenis penelitian ini menggunakan metode analitik korelatif dengan pendekatan cross-sectional karena pengambilan data hanya sekali dalam satu waktu sehingga seluruh responden diukur pada saat bersamaan. Tempat penelitian ini dilakukan di RT.11/RW.12 Kelurahan Jatinegara Jakarta Timur. Waktu penelitian dilakukan pada bulan Februari 2021. Pada penelitian ini peneliti menggunakan metode probability sampling dengan teknik total sampling yaitu mengambil seluruh anggota populasi untuk dijadikan sampel (Notoatmodjo, 2012). Untuk menentukan jumlah sampel minimal penelitian ini menggunakan teknik slovin. Berdasarkan hasil dari perhitungan rumus slovin, sampel minimal pada penelitian ini berjumlah 116 dengan tambahan persentase $10 \%$ maka jumlah sampel yang diteliti berjumlah 128 orang.

Kriteria inklusi dan kriteria eksklusi pada penelitian ini sebagai berikut : kriteria Inklusi penelitian ini diantaranya sehat jasmani dan rohani, dapat membaca, bersedia dan sukarela dijadikan sampel, berusia lebih dari 17 tahun. Kriteria eksklusi pada penelitian ini adalah warga yang memiliki keterbatasan dengan teknologi.

\section{HASIL}

Tabel 1. Distribusi Frekuensi Berdasarkan Usia dan Pendidikan

\begin{tabular}{|c|c|c|c|}
\hline No. & Karakteristik & Jumlah & Persentase (\%) \\
\hline \multicolumn{4}{|c|}{ 1. Usia } \\
\hline & a. Remaja & 50 & $39,1 \%$ \\
\hline & b. Dewasa dan Seterusnya & 78 & $60.9 \%$ \\
\hline \multicolumn{4}{|c|}{ 2. Pendidikan } \\
\hline & a. Rendah & 9 & $7 \%$ \\
\hline & b. Tinggi & 119 & $93 \%$ \\
\hline
\end{tabular}

Dari hasil penelitian didapatkan responden yang berusia $<26$ tahun atau remaja sebanyak 50 orang $(39,1 \%)$ dan berusia $>26$ tahun atau dewasa dan seterusnya sebanyak 78 orang $(60,9 \%)$.
Dan hasil penelitian pada pendidikan didapatkan responden pada kategori rendah sebanyak 9 orang (7\%), dan pada kategori tinggi sebanyak 119 orang $(93 \%)$ (tabel 1$)$.

Tabel 2. Distribusi Frekuensi Berdasarkan Pengetahuan, Sikap, Dan Kepatuhan

\begin{tabular}{llcc}
\hline \multicolumn{1}{c}{ Karakteristik } & Jumlah & Persentase (\%) \\
\hline 1. & Pengetahuan & & \\
& a. Kurang Baik & 14 & $10,9 \%$ \\
b. Baik & 114 & $89.1 \%$ \\
\hline 2. Sikap & & \\
$\quad$ a. Negatif & 20 & $15,6 \%$ \\
b. Positif & 108 & $84,4 \%$ \\
\hline $3 \quad$ Kepatuhan & & \\
& c. Tidak Patuh & 45 & $35,2 \$$ \\
d. Patuh & 83 & $64,8 \%$ \\
\hline
\end{tabular}

Dapat diketahui distribusi orang $(89,1 \%)$. dapat diketahui frekuensi pengetahuan warga distribusi sikap warga RT.11/RW.12 RT.11/RW.12 Jatinegara Jakarta Timur Jatinegara Jakarta Timur pada kategori pada kategori kurang baik sebanyak 14 kurang baik sebanyak 20 orang orang $(10,9 \%)$, dan baik sebanyak $114 \quad(15,6 \%)$, dan baik sebanyak 108 orang 
$(84,4 \%)$. dapat diketahui distribusi kepatuhan penerapan 3M pada warga RT.11/RW.12 Jatinegara Jakarta Timur pada kategori kurang baik sebanyak 45 orang $(35,2 \%)$, dan baik sebanyak 83 orang $(64,8 \%)$ (tabel 2$)$.

Tabel 3. Analisis Data Chi-Square

\begin{tabular}{llcccl}
\hline \multirow{2}{*}{ No } & \multirow{2}{*}{ Variabel } & \multicolumn{3}{c}{ Kepatuhan } & \multirow{2}{*}{ Keterangan } \\
\cline { 3 - 5 } & & $\mathbf{p}$ & $\mathbf{O R}$ & $\mathbf{9 5 \%} \mathbf{C I}$ & \\
\hline 1 & Pengetahuan & 0,034 & 3,900 & $1,22-12,47$ & Ada Hubungan \\
\hline 2 & Sikap & 0,000 & 10,897 & $3,36-35,29$ & Ada Hubungan \\
\hline
\end{tabular}

Hasil analisis hubungan antara pengetahuan warga RT.11/RW.12 Jatinegara Jakarta Timur dengan kepatuhan penerapan 3M diperoleh bahwa di antara 14 Warga yang memiliki pengetahuan kurang baik, terdapat 9 orang $(64,3 \%)$ warga yang kurang baik dalam menerapkan 3M, dan 5 orang $(35,7 \%)$ yang baik dalam menerapkan 3M. Sementara di antara 114 warga RT.11/RW.12 Jatinegara Jakarta Timur yang memiliki pengetahuan baik, terdapat 36 orang $(31,6 \%)$ yang kurang baik dalam menerapkan $3 \mathrm{M}$, dan 78 orang $(68,4 \%)$ yang baik dalam menerapkan 3M. Hasil uji statistik diperoleh nilai $\mathrm{p}=0,034$ $(<0,05)$, maka diambil kesimpulan bahwa Ha diterima, dan HO ditolak, dengan demikian dapat dikatakan bahwa ada hubungan antara pengetahuan warga RT.11/RW.12 Jatinegara Jakarta Timur dengan kepatuhan penerapan 3M. Dari hasil analisis diperoleh pula nilai $\mathrm{OR}=3,900$, artinya warga dengan pengetahuan yang kurang baik mempunyai resiko 3,9 kali lebih besar untuk kurang baik dalam menerapkan 3M dibandingkan dengan warga yang memiliki pengetahuan baik.

Hasil analisis hubungan antara sikap warga RT.11/RW.12 Jatinegara Jakarta Timur dengan kepatuhan penerapan 3M diperoleh bahwa di antara 20 warga yang memiliki sikap negatif, terdapat 16 orang $(80,0 \%)$ yang kurang baik dalam menerapkan $3 \mathrm{M}$, dan 4 orang $(20,0 \%)$ yang baik dalam menerapkan 3M. Sementara di antara 108 warga yang memiliki sikap positif, terdapat 29 orang (26,9\%) warga yang kurang baik dalam menerapkan 3M, dan 79 orang $(73,1 \%)$ yang baik dalam menerapkan 3M. Hasil uji statistik diperoleh nilai $p=0,000$ $(<0,05)$, maka diambil kesimpulan bahwa Ha diterima, dan HO ditolak, dengan demikian dapat dikatakan bahwa ada hubungan yang signifikan antara sikap warga RT.11/RW.12 Jatinegara Jakarta Timur dengan kepatuhan penerapan 3M. Dari hasil analisis diperoleh pula nilai $\mathrm{OR}=10,897$, artinya warga dengan sikap negatif mempunyai resiko 10,9 kali lebih besar untuk kurang baik dalam menerapkan 3M dibandingkan dengan pekerja yang memiliki sikap positif (tabel3).

\section{PEMBAHASAN \\ Karakteristik Responden}

\section{Usia}

Hasil penelitian ini sejalan dengan penelitian yang dilakukan oleh Afrianti dan Rahmiati (2021) dimana terdapat hubungan antara usia terhadap penerapan protokol kesehatan COVID19 dengan hasil analisis bivariat $(p=0,001)$. Tingkat kematangan dan kekuatan seseorang akan lebih matang dalam berpikir dan bekerja seiring dengan bertambahnya umur. Dari segi kepercayaan, masyarakat lebih mempercayai orang yang lebih dewasa daripada orang yang belum cukup tinggi tingkat kedewasaannya. Hal ini berkaitan dengan pengalaman dan kematangan jiwanya. Semakin dewasa seseorang, maka cara berpikir semakin matang (Niven, 2008).

\section{Pendidikan}

Hasil penelitian ini sejalan dengan penelitian yang dilakukan oleh Afrianti dan Rahmiati (2021) dimana terdapat hubungan antara pendidikan terhadap penerapan protokol kesehatan COVID19 dengan hasil analisis bivariat $(p=0,035)$. 
Menurut Niven (2008) pendidikan adalah usaha sadar dan terencana untuk mewujudkan suasana belajar dan proses pembelajaran agar peserta didik secara aktif mengembangkan potensi dirinya untuk memiliki kekuatan spiritual keagamaan, pengendalian diri, kepribadian, kecerdasan, akhlak mulia, serta keterampilan yang diperlukan dirinya, masyarakat, bangsa, dan negara. Pendidikan seseorang dapat meningkatkan kepatuhan, sepanjang bahwa pendidikan tersebut merupakan pendidikan yang aktif.

\section{Hubungan Antara Pengetahuan Dengan Kepatuhan Penerapan 3M}

Hasil penelitian ini sejalan dengan penelitian yang dilakukan oleh Afrianti dan Rahmiati (2021) dimana terdapat hubungan antara pengetahuan terhadap protokol kesehatan COVID-19 dengan hasil analisis bivariat $(p=0,015)$. Dimana terdapat $74,2 \%$ masyarakat yang memiliki pengetahuan tinggi terhadap COVID-19 dan 89,6\% masyarakat yang memiliki kepatuhan yang baik terhadap protokol kesehatan COVID-19. Hal yang sama juga didapatkan oleh Sari, Nabila, dan Atiqoh (2020) dimana terdapat 69,35\% masyarakat memiliki pengetahuan yang baik terhadap COVID-19 dan 74,19\% masyarakat memiliki tingkat kepatuhan yang tinggi dalam penggunaan masker, serta hasil analisa bivariat didapatkan adanya hubungan antara pengetahuan masyarakat dengan kepatuhan menggunakan masker sebagai salah satu protokol kesehatan COVID-19.

Pengetahuan dapat diperoleh seseorang secara alami atau diintervensi baik langsung maupun tidak langsung. Perkembangan teori pengetahuan telah berkembang sejak lama. Filsuf pengetahuan yaitu Plato menyatakan pengetahuan sebagai "kepercayaan sejati yang dibenarkan (valid)" (justified true belief). Pengetahuan merupakan hasil dari tahu dan ini terjadi setelah orang melakukan pengindraan terhadap suatu objek tertentu. Dalam Kamus Besar Bahasa Indonesia, pengetahuan adalah sesuatu yang diketahui berkaitan dengan proses pembelajaran. Proses belajar ini dipengaruhi berbagai faktor dari dalam, seperti motivasi dan faktor luar berupa sarana informasi yang tersedia, serta keadaan sosial budaya. Pengetahuan sangat erat kaitannya dengan pendidikan di mana diharapkan seseorang dengan pendidikan tinggi akan semakin luas pula pengetahuannya. Namun, perlu ditekankan bahwa seorang yang berpendidikan rendah tidak berarti mutlak berpengetahuan rendah pula. Peningkatan pengetahuan tidak mutlak diperoleh di pendidikan formal, akan tetapi juga dapat diperoleh pada pendidikan nonformal, seperti penyuluhan yang dilakukan oleh tenaga kesehatan (Budiman dan Riyanto, 2013).

Pengetahuan merupakan domain yang sangat penting untuk terbentuknya tindakan seseorang. Pengetahuan diperlakukan sebagai dukungan dalam menumbuhkan rasa percaya diri maupun sikap dan perilaku setiap hari, sehingga dapat dikatakan bahwa pengetahuan merupakan fakta yang mendukung tindakan seseorang. Salah satu faktor yang dapat mempengaruhi kepatuhan adalah pengetahuan. Seorang warga yang mempunyai pengetahuan 3M yang baik, diharapkan akan menerapkan pengetahuannya dalam kepatuhan penerapan 3M. Antara pengetahuan, sikap, niat, dan perilaku akan mempengaruhi keikutsertaan seseorang dalam aktivitas tertentu. Adanya pengetahuan terhadap manfaat suatu hal akan menyebabkan penderita mempunyai sikap yang positif terhadap hal tersebut (Notoatmodjo, 2012).

\section{Hubungan Antara Sikap dengan Kepatuhan Penerapan 3M}

Hasil penelitian ini sejalan dengan penelitian yang dilakukan oleh Afrianti dan Rahmiati, (2021) dimana terdapat hubungan antara sikap terhadap protokol kesehatan COVID-19 dengan hasil analisis bivariat $(p=0,006)$. Dimana terdapat $76,1 \%$ masyarakat yang memiliki sikap yang positif terhadap COVID-19 dan 89,6\% 
masyarakat yang memiliki kepatuhan yang baik terhadap protokol kesehatan COVID-19. Hasil yang sama diperoleh oleh Purnamasari, Ika. Raharyani, A. E. (2020) dimana masyarakat cenderung memiliki sikap yang positif dalam menghadapi pandemi COVID-19 (59\%). Wiranti, Ayun dan Wulan (2020) juga mempertegas hasil penelitian yang didapat dimana masyarakat juga sudah dominan memiliki sikap yang positif dalam menghadapi COVID-19 (65,2\%).

Sikap adalah respon tertutup seseorang terhadap stimulus atau objek, sehingga manifestasinya tidak dapat langsung dilihat, tetapi hanya dapat langsung ditafsirkan terlebih dahulu dari perilaku yang tertutup. Sikap secara nyata menunjukan konotasi adanya kesesuaian reaksi terhadap stimulus yang merupakan reaksi bersifat emosional terhadap stimulus sosial. Sikap merupakan kesiapan atau kesediaan untuk bertindak, dan bukan merupakan pelaksanaan motif tertentu (Notoatmodjo, 2012).

Di antara responden dengan sikap yang baik, masih terdapat responden dengan kepatuhan penerapan $3 \mathrm{M}$ yang kurang baik. Hal ini disebabkan karena sikap belumlah merupakan suatu tindakan atau aktivitas, akan tetapi merupakan predisposisi tindakan suatu perilaku. Sikap merupakan reaksi tertutup, bukan reaksi terbuka atau tingkah laku yang terbuka dan sikap merupakan kesiapan seseorang untuk bereaksi terhadap objek dilingkungan tertentu sebagai suatu penghayatan terhadap objek. Suatu sikap tertentu belum bisa menunjukkan tindakan dari seseorang. Untuk mewujudkan sikap menjadi suatu tindakan yang nyata diperlukan faktor pendukung atau suatu keadaan yang juga dapat mendukung tindakan tersebut (Notoatmodjo, 2012)

\section{Keterbatasan Penelitian}

Dalam penelitian ini komunikasi antara peneliti dan responden pada saat melakukan penelitian menggunakan kuesioner terbilang sulit karena dilakukan secara online, sehingga banyak responden yang tidak mengerti penjelasan awal sebelum melakukan pengisian kuesioner.

\section{KESIMPULAN}

Faktor yang terbukti berpengaruh terhadap kepatuhan penerapan 3M adalah pengetahuan dan sikap. Diharapkan untuk dinas kesehatan ataupun petugas yang berwenang untuk dapat terus meningkatkan program kepatuhan penerapan 3M pada masyarakat sesuai dengan hasil penelitian ini, yaitu faktor Pengetahuan dan sikap masyarakat agar dapat tertekannya angka peningkatan kasus COVID-19.

\section{SARAN}

Bagi masyarakat khususnya warga RT.11/RW.12 untuk terus mentaati protokol kesehatan khusunya 3M agar tertekannya angka COVID-19 di Indonesia.

\section{DAFTAR PUSTAKA}

Afrianti dan Rahmiati. (2021). Faktorfaktor Yang Mempengaruhi Kepatuhan Masyarakat Terhadap Protokol Kesehatan COVID-19. Sekolah Tinggi Ilmu Kesehatan Kendal. 11(1): 113-124.

Budiman dan Riyanto. (2013). Kapita Selekta Kuesioner Pengetahuan Dan Sikap Dalam Penelitian Kesehatan. Jakarta: Salemba Medika.

Isbaniyaah, F. Saputro, D. Sitompul, A. Manalu, R. Setyawati, V. Kandun, N. et al. (2020). Pedoman Pencegahan Dan Pengendalian Coronavirus Disease (COVID-19). Revisi ke 3. Jakarta : Kementerian Kesehatan RI Direktorat Jenderal Pencegahan dan Pengendalian Penyakit (P2P).

Niven. (2008). Psikologi Kesehatan : Pengantar Untuk Perawat Dan Profesional. Jakarta : EGC.

Notoatmodjo. (2012). Metodologi Penelitian Kesehatan. Jakarta: Rineka Cipta.

Notoatmodjo. (2012). Promosi Kesehatan Dan Perilaku Kesehatan. Revisi 2012. Jakarta: Rineka Cipta.

Pemprov DKI Jakarta. (2020). Data Pemantauan COVID-19. Jakarta. Available at 
https://corona.jakarta.go.id/id (accessed : 5 September 2020).

Purnamasari, Ika. Raharyani, A. E. (2020). Tingkat Pengetahuan Dan Perilaku Masyarakat Kabupaten Wonosobo Tentang Covid-19. Jurnal Ilmiah Kesehatan 10(1): 33-42.

Sari, Nabila, dan Atiqoh. (2020). Hubungan Antara Pengetahuan Masyarakat Dengan Kepatuhan Penggunaan Masker Sebagai Upaya Pencegahan Penyakit Covid-19 di Ngronggah. Rekam Medis Dan Informasi Kesehatan 10(1): 52-54.

Wiranti, Ayun. dan Wulan. (2020). Determinan Kepatuhan Masyarakat Kota Depok terhadap Kebijakan Pembatasan Sosial Berskala Besar dalam Pencegahan COVID-19. Jurnal Kebijakan Kesehatan Indonesia 09 (03): 117-124.

WHO. (2020). Anjuran Mengenai Penggunaan Masker Dalam Konteks COVID-19. Available at : tember 2020). https://www.who.int/docs/defaultsource/searo/indonesia/covid19/anj uran-mengenai-penggunaanmasker-dalam-konteks-covid-19june-20.pdf?sfvrsn=d1327a85_2 (accessed : 13 Oktober 2020).

WHO. (2020). WHO Director-General's opening remarks at the media briefing on COVID-19 - 11 March 2020. Available at : https://www.who.int/dg/speeches/d etail/who-director-general-sopening-remarks-at-the-mediabriefing-on-covid-19---11-march2020 (accessed : 5 September 2020).

Yulisman. (2020). Mother and daughter test positive for coronavirus in Indonesia, first confirmed cases in the country. Available at : https://www.straitstimes.com/asia/ se-asia/indonesia-confirms-twocoronavirus-cases-president (accessed : $\quad 5 \quad$ Sep 